\title{
Reklamın Dramaturjik Çerçevede Çözümlenmesi: Absürt Dramaturji Açısından Bir Televizyon Reklamı
}

\section{Analysis of Advertisement within a Dramatic Framework: A TV Commercial in Terms of Absurd Dramaturgy}

\author{
Serdar YILDIZ ${ }^{1 \oplus}$
}

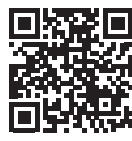

${ }^{1}$ Res. Asst., Anadolu University, Faculty of Communication Sciences, Department of Public Relations and Advertising, Eskişehir Turkey

Sorumlu yazar/Corresponding author: Serdar Yıldız,

Anadolu Üniversitesi, İletişim Bilimler Fakültesi, Halkla İlişkiler ve Reklamcılık Bölümü, Eskişehir, Türkiye

E-posta/E-mail: serdar.y@anadolu.edu.tr

Geliş tarihi/Received: 24.04 .2018 Kabul tarihi/Accepted: 16.11.2018

Atıf/Citation: Yıldız, S. (2018). Reklamın dramaturjik çerçevede çözümlenmesi: Absürt dramaturji açısından bir televizyon reklamı. Connectist: Istanbul University Journal of Communication Sciences, 55, 197-227. https://doi.org/10.26650/CONNECTIST2018-0002
Öz

$\mathrm{Bu}$ çalışma, disiplinlerarası bir alan olan reklamcılığın farklı bilim dallarıyla olduğu kadar, sanatla da yakından ilişkili olduğu düşüncesinden hareketle gerçekleştirilmiştir. Araştırmada, Stern'in (1990) pazarlama ve tiyatro arasındaki ortaklıktan yola çıkarak, reklamı dramaturjik çerçevede değerlendirdiği çalışması temel alınmıştır. Bu kapsamda absürt bir reklam örneği olarak, Eti Tutku markasının bir televizyon reklamı, absürt dramaturji açısından çözümlenmiştir. Böylece, reklamın dramaturjik çerçevede çözümlenmesine bir örnek sunmak ve çözümlenen reklam üzerinden, reklamda absürtlüğü teatral bir çerçevede değerlendirmek amaçlanmıştır. Çözümleme sonucunda reklamın, "tema, eylem, sahne, karakter, dil ve ton" unsurlarının tamamı açısından absürt anlatım biçimini kullandığı ve absürt tiyatro eserleriyle benzerlikler taşıdığı görülmüştür. Böylece, absürt bir anlatı olarak değerlendirilen reklam üzerinden; felsefe, edebiyat ve sanat alanlarında dikkat çeken absürt kavramının, kitle iletişim alanına yansımaları tartışılmıştır. Sonuç olarak, bu tarz reklamların yarattığı anlam ile birlikte, reklamcılıkta absürt strateji ve anlatım biçiminin kullanımına ilişkin çıkarımlar sunulmuş; reklam ve sanat ilişkisi üzerine yapılandırılabilecek araştırma önerilerine yer verilmiştir.

Anahtar Kelimeler: Televizyon reklamı, reklam çözümlemesi, absürt, dramaturji, nitel araştırma

\section{ABSTRACT}

This study was carried out with the thought that, as an interdisciplinary field, advertising is closely related to art as well as to various branches of science. The research is grounded on Stern's (1990) study of advertising within a dramatic framework, with reference to the relationship between marketing and theatre. In this context, we analyzed Eti Tutku's TV commercial as an example of absurd advertisement, in terms of absurd dramaturgy. Our aim is to present an example of advertisement analysis within a dramatic framework and to evaluate the absurdity in advertising from a theatrical perspective. As a result of the study, we found that the commercial uses the absurd narrative form in terms of "theme, 
action, setting, character, language, and tone" and that it shares similarities with absurd theatre plays. The term "absurd" originates from philosophy, literature, and art. By studying a commercial that is considered an absurd narrative, we discussed its traces on the field of mass communication. In addition to the meaning created by such advertisements, we present implications of using absurdist strategy and narration in advertising, and also suggestions for future research that could be structured on the relationship between advertising and art.

Keywords: TV commercial, advertising analysis, absurd, dramaturgy, qualitative research

\section{EXTENDED ABSTRACT}

As an interdisciplinary field, advertising is closely related to art as well as to various branches of science. Researchers have been investigating this relationship using methods such as content analysis (Hetsroni \& Tukachinsky, 2005), semiotics (Okat Özdem \& Geçit, 2013), literary analysis (Stern, 1991; Etienne \& Vanbaelen, 2006), art and literary criticism (Stern \& Schroeder, 1994), textual analysis (Stern, 1996), and multimodal analysis (Periasamy, Gruba \& Subramaniam, 2015). Most of these studies are grounded in the theories and concepts of art, literature, and narratology.

The art of theatre also shares similarities with advertising, particularly in audiovisual forms such as TV commercials. Esslin (1996) argues that a great deal of television content, such as advertisements, should be considered within the field of drama. Drama theory and dramaturgy has been adapted to marketing and consumer behavior studies using a variety of different perspectives. Stern (1990) used dramaturgy to analyze advertisements as dramatic texts and discussed absurdity in advertising in terms of theme, action, setting, character, language, and tone.

In this study, we analyzed a TV commercial of Eti Tutku, in terms of absurd dramaturgy. In this way, we presented an example of advertisement analysis in dramatic framework and evaluated absurdity in advertising on a theatrical basis. Using a commercial that is considered an absurd narrative, we discussed the term absurd on the field of mass communication.

The term absurd is often used to describe meaningless, bizarre, extraordinary or irrational events and situations. Beyond that, absurdism represents an existentialist philosophical thought based on the idea that humanity and the universe cannot be explained by reason, logic, and congruity. This idea happened as a response to the collapse of the great ideals such as rationalism and modernism, which were 
presented to humanity in the $20^{\text {th }}$ century. Absurdism had a great influence on different literary and artistic fields, and also created the modern theatre movement called "Theatre of the Absurd" (Esslin, 1999). To describe the absurd state of humanity, absurd plays depict bizarre characters, unrealistic settings, nonsense language, and events that do not rely on cause-and-effect relationships. Eventually, absurdist expression crossed the boundaries of theatre and can now be seen in cinema, television, and advertising.

Stern (1990, p. 192) argues that absurdity is used as a dramatic form in advertising. Advertisers often take advantage of creative elements such as absurdity to capture consumers' attention and gain a place in their minds in the advertising clutter. AriasBolzmann (1993, p. 3) defines absurdity in advertising as "the incongruous juxtaposition of pictorial images, words, and/or sounds that viewers perceive to be unique, irrational, bizarre, illogical, or disordered." Stern (1990, p. 197) states that absurd dramas depict non-rational, ambiguous, and meaningless worlds rather than orderly, meaningful, and value-laden ones found in traditional realistic dramas. Accordingly, a playwright of the absurd shows the true nature of the world and lets the audience decide how best to cope with it. According to Stern, a brand that claims to be absurdist, acknowledges that the world and its own are imperfect. By making fun of this situation, an absurdist brand seeks to inspire trust and sympathy and lets the consumer choose whatever is personally best in an environment of uncertainty.

The commercial that is subject to analysis in this study (Image 1) begins with opening a door on which is written "Eti Tutku Customer Services." The opening of the door, which evokes the opening of a theatre curtain, prepares the viewer for an advertising narrative that depicts events between the brand and the customer. As understood from the dialogue, a customer is here for a kind of coffee fortunetelling. The customer representative acts as a fortuneteller by using the fluid chocolate cream of Tutku biscuit. The other characters, including the customer and a bizarre man and woman, respond to her senselessly. The commercial ends with a description of the product features, such as "delicious fluid chocolate cream."

The theme of the advertisement is based on meaningless and ambiguous messages like absurd narratives. The brand presents the product feature, fluid cream, in an unrelated manner to its real benefit. Thus, the brand makes use of a sympathetic way of persuasion by making fun of itself and the advertising world's idealized promises. 
The main action in the ad is the act of fortunetelling by using the cream of a biscuit, and this seems meaningless and purposeless. It is totally unclear why the characters do that, or what happens as a result. The only meaningful message of the ad is that the Tutku biscuit's chocolate cream is fluid and delicious. This is also the most important promise of the brand to consumers.

As in an absurd play, the setting is discordant because the place that resembles a spaceship or an empty studio is decorated like a living room of an ordinary house. It is seen that the place presented as a customer service unit is a strange and unreal place with a very low probability to be encountered in everyday life.

Characters can be regarded as absurd with their appearance, speech and behaviors. In particular, the male and female characters that appear like copies of each other seem as if they were taken from an absurd theatre play. These characters, which resemble car crash test dummies with biscuit images on their temples, act in exaggerated and meaningless behaviors and contribute to the perception of uncertainty in the ad. Acting is also in an exaggerated style in accordance with absurd plays.

The language used in the ad can be considered absurd with regard to dialogues and mimes, which do not make any sense to the audience. Dialogues are full of ambiguous and meaningless words. Characters respond to each other's meaningless words as if they are very important. The contradiction between the spoken words and their meaning is remarkable.

The ad has a sarcastic and humorous tone as is found in absurd plays. With this ad, the brand subjects itself and its product to ridicule and humor. The brand also makes fun of the advertising world's idealized promises. This can be considered parody, which is another characteristic of absurd plays.

As a result of the analysis, we can see that the commercial uses the absurd narrative form in terms of dramaturgical framework and shares similar characteristics with absurd plays. The brand conveys an absurd and ambiguous message, contrary to many brands that present ideal values like happiness, trust, freedom, or being the best. It seems inexplicable why the brand chose to use a worthless, meaningless, or absurd theme. However, in the cluttered advertising environment, it is possible that 
absurdism may be the right choice for attracting consumers who are weary of idealized promises.

In summary, we can argue that Eti Tutku adopted the absurdist strategy and preferred absurd narration in its ad. This can be considered a literary or artistic reflection on mass communication. In addition to this study, future research that focuses on different literary and artistic aspects such as narrative formats, metaphor, musical elements, graphic design, photography, and visual arts will contribute significantly to the field of advertising. 


\section{GíRiş}

Esslin (1996, p. 9) televizyonda sunulan reklam ve benzeri pek çok içeriğin, dram sanatının alanı içerisinde değerlendirilmesi gerektiği savunmaktadır. Yazar, dram sanatının doğası ve tekniği üzerine yazılanların yalnızca sahnedeki gösteriye odaklanma eğilimini ve gerek tiyatro kuramcılarının, gerek sinema eleştirmenlerinin, televizyondaki drama ile yeterince ilgilenmemelerini eleştirmektedir. Oysa, milyonlarca seyirciye ulaşan dramatik malzemenin çok büyük bir bölümü ve dram sanatının geçirdiği deneyimlerin büyük bir parçası, tiyatrodan türetilerek sinemaya ve hepsinden çok da televizyona geçmiştir. Esslin'e göre, dramatik gösterinin tüm öğeleri tam anlamıyla ele alındığında; sahne, sinema ve televizyon gibi farklı araçların, kendilerinin saydıkları özelliklerinin ayrımına ulaşılabileceği gibi, daha çok sayıda öğenin de birbirinin aynı olduğu fark edilecektir.

Esslin'in eleştirisi konunun diğer tarafı olan iletişim bilimciler açısından da geçerlidir. Tıpkı drama üzerine çalışanların kitle iletişim içeriklerine mesafeli yaklaşması gibi, iletişim araştırmacılarının da çalışma alanları ile edebiyat ve özellikle tiyatro arasındaki ilişkiyle yeterli düzeyde ilgilenmedikleri gözlemlenmektedir. Örneğin, reklamcılık literatürü incelendiğinde, bu alandaki çalışmaların başta psikoloji olmak üzere, iletişim, pazarlama, sosyoloji ve antropoloji gibi alanların kavram, kuram ve yapılarına başvurduğu görülecektir (Kim, Hayes, Avant, \& Reid, 2014). Reklamın, burada anılan bilim dallarıyla ilişkili olduğu kadar, aynı zamanda edebiyat, tiyatro, sinema, fotoğraf, müzik, grafik tasarım gibi sanat alanlarıyla da yakın bir ilişki içerisinde olduğu açıktır. Bununla birlikte, reklamın sanat ile olan ilişkisinin alandaki araştırmacılardan hak ettiği ilgiyi görmediği, bu ilişkinin akademik çalışmalara yeterli ölçüde yansımadığı gözlemlenmektedir.

Bilindiği üzere reklamcılar, amaçları doğrultusunda sanattan yararlanmakta ve reklam yaratım sürecinde farklı sanat alanlarıyla temas halinde bulunmaktadır. Bunun sonucu olarak reklamların, bir biçimde sanatın farklı alanlarından izler taşıdığı düşünülebilir. Bu varsayımdan hareketle, reklam araştırmalarında sanata ait yöntem ve tekniklerden de yararlanılması mümkün görünmektedir. Bu çalışmada, reklam çözümlemesinde bir yöntem olarak, tiyatro metinlerinin çözümlenmesi ve sahneye uygulanması uğraşı olan dramaturjiden yararlanılmıştır. 
Stern'e göre (1990, p. 191) pazarlama uygulamalarıyla tiyatro eserleri arasında bir ortak nokta vardır; her ikisinde de "bir yazar (firma) okuyucuya (tüketiciye) bir metin (reklam) iletmektedir." Bu ortaklıktan yola çıkarak, absürt tiyatro hareketini pazarlama stratejisi ile ilişkilendiren ve reklamda absürtlüğü tiyatroya ait bir çerçevede, dramaturjiden yararlanarak inceleyen Stern, (1990) "tema, eylem, sahne, karakter, dil ve ton" unsurlarının absürt tiyatrodaki biçimlerini açıklamış ve bunları reklam örnekleriyle ilişkilendirmiştir.

Bu çalışmada ise absürt tiyatroya ait unsurları yoğun olarak barındırdığı düşünülen Eti Tutku markasının bir televizyon reklamı (Eti Tutku, 2011), Stern'in çalışmasına benzer biçimde dramaturjik unsurlar açısından çözümlenmiştir. Bu doğrultuda öncelikle reklam ve sanat ilişkisi tartışılarak, reklamın edebiyat ve sanatla ilişkili boyutu üzerine odaklanan çalışmalar derlenmiştir. Ardından, gerçekleştirilen çözümlemeye temel oluşturması amacıyla absürt kavramı ve reklamda absürtlük konusuna değinilmiş ve ilgili reklam çözümlenerek, reklam yaratım süreci ve reklamda anlamın üretimi üzerine bir tartışma sunulmuştur.

\section{Reklam ve Sanat Iliş̧kisi}

Reklamcılık, kimilerine göre çağımızın sanatı olarak kabul edilirken, kimilerine göre bu iki uğraşın birlikte anılması dahi sanata haksızlık yapmak anlamına gelmektedir. Örneğin, McLuhan'ın reklamcılığı "20. yüzyılın en büyük sanat türü" olarak ilan etmesi gibi, Rutherford (2000, p. 16) da reklamları "zamanımızın sanatı" olarak kabul etmektedir. Öte yandan Baudrillard'ın sanatın bir süre sonra yerini reklamcılığa bırakarak yok olacağı öngörüsüne paralel olarak, reklamcılığın sanata zarar verdiği düşüncesi "meta estetiği" gibi kavramlar odağında tartışılmaktadır.

Bu tartışmada, sanat ve reklamın amaçları açısından farklı olduğu ve ticari kaygılarla yönlendirilen bir uğraşın sanatsal bir etkinlik olarak değerlendirilemeyeceği görüşü öne çıkmaktadır. Reklam ve sanat ilişkisi konusunda kapsamlı bir inceleme sunan Alıcı (2014, p. 112) da sanatsal bir çabası olsa dahi amacı önceden belirlenmiş olduğundan reklamcının bir sanatçı gibi özgür irade ortaya koyamayacağına dikkat çekmiştir. Şüphesiz ki reklamcılar, sanatçılardan farklı olarak; markanın amaçları, pazar koşulları, ürün ve tüketici özellikleri gibi unsurlarla sınırlandırımıştır. Fakat, bu sınırlı alan içerisinde dahi olsa reklam yaratıcılarından beklenen, her gün binlerce reklam mesajına maruz kalan tüketicileri yakalamak ve ikna etmek için ticari kaygıları estetik kaygılarla 
birleştirerek yaratıcı reklam çözümleri sunmalarıdır. Bu durum, zaman zaman reklamcıları sanatsal yaratım sürecine benzer biçimde çalışmaya ya da bir başka açıdan bakıldığında, sanatı kendi amaçları doğrultusunda kullanmaya yönlendirmektedir.

Bu noktada John Berger'in Görme Biçimleri kitabındaki görüşlerine de değinmek gerekir. Berger (2007, p. 134) bu eserinde, reklam ve sanat ilişkisini eleştirel bir yaklaşımla değerlendirse de reklamlarda eski sanat yapıtlarına uzanan çizgiler görüldüğünü, hatta bazen bir reklam imgesinin tümünün çok ünlü bir resmin açık bir benzeri olduğu gözlemini de dile getirir. Yazara göre, reklamlarla söz konusu sanat eserleri arasındaki ilişki yalnızca bir tür alıntı yapılmasıyla da sınırlı değildir. Reklamcıların, resim sanatının inceliklerini pek çok sanat tarihçisinden daha iyi kavradığını belirten Berger, reklamlarda büyük ölçüde yağlı boya resim dilinin kullanıldığını gözlemlemektedir.

Reklamcılığın bir sanat alanı olarak kabulü ve reddi konusundaki tartışmadan bağımsız olarak; reklam yaratım sürecinin yaratıcılığı gerekli kılması, bu süreçte farklı sanat alanlarıyla temas halinde olunması ve tüketicileri etkilemek için ticari kaygıların yanı sıra estetik kaygıların da güdülmesi reklamı sanata yaklaştırmakta ya da en azından reklam ve sanat arasındaki ilişkiyi ortaya koymaktadır. Özellikle, Pop Art gibi postmodern sanat hareketlerinin, reklam ve sanat arasındaki sınırın giderek yok olmasına neden olduğu da tartışılmaktadır.

Reklamın sanatla ilişkisini ele alan araştırmacılar, genellikle göstergebilimsel çözümleme ve içerik analizi gibi yöntemleri kullanarak reklamda sanatın izlerini araştırmaktadırlar. Bu bağlamda, güzel sanatların reklamlarda kullanımı (Hetsroni \& Tukachinsky, 2005); klasik sanat eserleri ile reklamlar arasındaki bağlantılar (Karabacak, 2013) ve postmodern sanat akımlarının reklamlara yansımaları (Kılıç Taran, 2017; Okat Özdem \& Geçit, 2013) gibi çalışmalar dikkat çekmektedir. Bu noktada özellikle, reklamı edebi bir metin olarak ele alan ve bu metni çözümlemek üzere edebiyat alanındaki birikimden yararlanan çalışmalardan da söz etmek gerekir. Bu çalışmalarda reklamlar; edebi çözümleme (Etienne \& Vanbaelen, 2006; Stern, 1991); sanat ve edebiyat eleştirisi (Stern \& Schroeder, 1994); metin analizi (Stern, 1996) ve çok modlu analiz (Periasamy et al., 2015) gibi yöntemlerle çözümlenmektedir.

Reklamı bir metin olarak değerlendirme yaklaşımı "anlatısal reklam" (narrative advertising) konusunda ise gerek içerik çözümlemeleri, gerek etki araştırmaları 
biçiminde kendini göstermektedir. Bu konuda gerçekleştirilmiş olan çalışmalarda, reklam dramalarının farklı türleri (Stern, 1994); öykülerin yapısı ve reklam anlatıları (Escalas, 1998); reklamların dramatik yapıları (Quesenberry \& Coolsen, 2014) ve reklamda metaleptik kullanımlar (Yılmaz, 2017) gibi konular, reklamın özellikle edebiyat ve anlatıbilim ile olan ilişkisi açısından dikkat çekmektedir.

Bir metnin sahnede canlandırılması biçiminde gerçekleşen tiyatro sanatı ise yalnızca metin üzerinde var olan edebi anlatıyı; sahne tasarımı, ışık, ses, oyunculuk vb. öğelerle birlikte sunarak çok boyutlu bir anlatım biçimine dönüştürmektedir. Bu anlatım biçimi özellikle televizyon gibi görsel-işitsel reklam mecralarındaki anlatım diliyle benzerlikler göstermektedir. Televizyon reklamlarını bir tür drama olarak değerlendiren Esslin'e (1979, p. 101) göre, reklam anlatısının sanatsal izleri yalnızca modern tiyatro eserlerine değil; tiyatronun köklerine, antik dönemlerdeki oyunlara kadar uzanmaktadır. Örneğin, Antik Yunan tiyatrosundaki yarı tanrı ya da tanrıça temsilleri ile günümüz reklamlarında sıklıkla karşılaşılan ünlü kullanımının benzer bir işlevi karşıladığı düşünülmektedir.

Stern'in (1990) reklam çözümlemesine yeni bir yaklaşım sunmak amacıyla, pazarlama ve tiyatro arasında kurduğu ilişki ve bu ilişkiden hareketle gerçekleştirilen çalışmalar yalnızca reklam içeriklerini çözümlemekle sınırlı değildir. Bu yaklaşım, pazarlama, marka iletişimi, tüketici davranışları gibi alanlarda farklı araştırma problemlerine yanıt aramak amacıyla da kullanılmaktadır. Buna ek olarak, tiyatro sanatı ve dramaturji kavramına sosyal bilimlerin farklı alanlarında, insan ilişkilerini ve davranışlarını açıklamak için de başvurulmaktadır. Tıpkı Shakespeare'in bütün dünyayı bir sahne olarak değerlendirmesi gibi, Goffman (2016) da gündelik yaşamın kendisini bir sahne, bireyleri de oyuncular olarak ele almakta ve insan davranışlarını dramaturji kavramından yararlanarak açıklamaktadır. Sosyoloji yazınında önemli bir yer tutan "izlenim yönetimi" kavramıyla ilişkili olan bu yaklaşım, insan ilişkilerine dair her konuda dramaturjiden yararlanılarak farklı bakış açıları geliştirmeye olanak sağlamaktadır.

Örneğin, Fisk \& Grove (1996) pazarlama faaliyetlerinin izlenim yönetimi kapsamında değerlendirilebileceğini belirtmişler ve Goffman'ın dramaturjik yaklaşımını pazarlama alanına uyarlamışlardır. Benzer şekilde, Moisio \& Arnould (2005) dramaturjik çerçeveden yararlanarak, tüketicilerin alışveriş deneyimleri üzerine etnografik bir araştırma tasarlamışlardır. Schulz, (2012) dramaturji yaklaşımını tüketici 
davranışı çalışmalarına uyarlamış; Meyer \& Schulz (2017) ise reklam ajansları ile tiyatro toplulukları arasındaki benzerliklere dikkat çekerek, reklam ajanslarının çalışmalarını araştırmak için dramaturjik çerçeveyi kullanmıştır.

Goffman'ın dramaturji yaklaşımı ve bundan hareketle gerçekleştirilen araştırmalar daha çok bireylerin gerçek hayattaki rolleri üzerine odaklanmaktadır. Örneğin birer tüketici olarak bireylerin günlük yaşamdaki rol ve davranışları, tüketici davranışı disiplini açısından ya da bireylerin bir örgüt içerisindeki rol ve davranışları yönetim organizasyon disiplini açısından değerlendirilmiştir. Buradaki yaklaşım ise reklamın kendisini bir anlatı, bir drama, bir metin olarak ele almakta ve dramaturjik yaklaşımı bu metni çözümlemek üzere kullanmaktadır.

Burada değinilen araştırma örneklerinin her biri, pazarlama, tüketici davranışı ve reklamcılık disiplinlerinin edebi ya da görsel sanatlarla ilişkisi üzerine inşa edilmiş çalışmalardır. Bu ilişki bazı çalışmalarda, araştırma tasarımı için gerekli kavramsal çerçeveyi sanatın kavram ve kuramlarından hareketle oluşturmakla sınırlı kalmış, bazılarında ise tıpkı burada dikkat çekilen yaklaşımda olduğu gibi araştırma yöntemi ya da veri toplama tekniği olarak doğrudan sanata ait tekniklere ve yöntemlere başvurmuşlardır.

\section{Absürt Kavramı}

Absürt ya da saçma sözcüğü genellikle anlamsız, tuhaf, sıra dışı veya akla aykırı olay ya da durumları açıklamak için kullanılır. Bununla birlikte absürt kavramı, felsefe ve sanatta bu gündelik kullanımdan çok daha fazlasını ifade etmektedir. Esslin'in (1999, p. 25) de belirttiği gibi aslında "müzikal anlamda armoniden yoksun" anlamına gelen absürt, yaygın kullanımda kısaca saçma olarak karşılık bulsa da ne Camus'nün insanlığın absürt durumunu açıklarken kullandığı ne de onun absürt tiyatrodan söz ederken kastettiği bu değildir.

Absürt kavramının kökeni felsefede 19. yüzyılın ilk yıllarına, Soren Kierkegaard'ın metinlerine kadar uzanıyor olsa da (Arias-Bolzmann, Chakraborty, \& Mowen, 2000, p. 36) asıl ortaya çıkışı ve etkisi 20. yüzyıla denk gelmektedir. Bu dönemde, aydınlanma çağı ve sanayi devriminin ışığında, insanlığa akıl ve bilimin öncülüğünde daha iyi bir dünya vaat edilirken yaşanan iki büyük dünya savaşı ve beraberinde getirdiği trajediler ciddi bir hayal kırıklığı yaratmıştır. Sanayileşme ve kapitalizmin refah 
toplumu yaratma amacı ise yeni toplumsal ve ekonomik sorunları beraberinde getirmiştir. Böyle bir ortamda insanlığa sunulan akılcılık, modernizmin vb. büyük anlatıların çöküşü, insanın ve evrenin akıl, mantık ve ölçülülük ile açıklanamayacağı düşüncesini doğurmuştur. Absürdizm olarak adlandırabileceğimiz bu felsefi kavrayış, edebiyat ve sanatın farklı alanlarında, yaşamın anlamsızlığı, dünyanın ve insanın uyumsuzluğu gibi temalar şeklinde karşılık bulmuştur.

Diğer sanat dallarından farklı olarak tiyatroda absürt, yeni bir anlatım biçimi olarak da karşılık bulur. Esslin'in (1999, p. 25) de belirttiği gibi insanlığın absürt durumu, absürt tiyatro için yalnızca bir konu değildir; bu durum anlatımla sahneye de yansır. Çoğu birbirinden habersiz olsa da aynı felsefi arka plandan hareketle benzer bir tiyatro anlayışını benimseyen absürt oyun yazarları, geleneksel tiyatronun alışılmış kurallarını yıkarak yeni bir dil ve anlatıma sahip olan absürt tiyatro hareketini yaratmışlardır. Samuel Beckett, Arthur Adamow, Eugene lonesco, Jean Genet ve Harold Pinter absürt tiyatro yazınının öncüleri olarak sıralanabilir (Esslin, 1999).

Absürt tiyatro, bir anlatım biçimi sunması sebebiyle, felsefe ve edebiyattaki karşılığına kıyasla, reklam anlatısındaki absürtlüğe daha yakın bir noktada durmaktadır. Bu anlatım biçiminin özellikleri ise genel olarak; ikna edici karakterler yerine, tanımlanması güç karakterler ve anlamsız eylemleri; zeki ve mantıklı kurgularla akıcı diyaloglar yerine, anlamsız gevezeliklere indirgenmiş diyaloglar; bir başlangıcı, gelişimi ve sonu olan kurgular yerine, rastgele başlayıp rastgele biten kurgular vb. şeklinde açıklanmaktadır (Çalışkan, 1995, p. 9). Şener'in (1998, p. 297) de belirttiği gibi absürt tiyatro, gerçeği mantıklı ve değişmez bir düzen olarak değil, anlaşılamayan ve açıklanamayan bir karmaşa olarak görür; bu uyumsuzluğun ancak geleneksel uyumların düzenini bozarak sahneye getirilebileceğini kabul eder ve oyunun yapısında, konuşma örgüsünde, görüntüde yeni ve akıl dışı düzenlemeler yapar. Söz konusu bu düzenlemeler ve absürt tiyatronun anlatım biçimi, aşağıda reklam çözümlemesi yapılırken dramaturjik unsurlar açısından ayrıca ele alınmıştır.

\section{Reklamda Absürtlük}

Felsefe, edebiyat ve sanattan; yaşamla ilgili pek çok farklı alandan beslenen reklamcılık da absürtlüğün etkisini gösterdiği bir alandır. Stern (1990, p. 192) reklamda 
absürtlüğü bir teatral biçim olarak, Arias-Bolzmann et al. (2000, p. 36) edebiyattan alınarak benimsenen bir form olarak açıklamışlardır. Baysal $(2008$, p. 43) ise kapitalizmin resmi sanat alanı kabul edilen reklamcılığı, absürdizmin etkilediği bir sanat alanı olarak yorumlamıştır.

Reklam yaratıcıları, reklam kirliliği içerisinde her an çok sayıda farklı iletiye maruz kalan tüketicileri yakalamak ve zihinlerde bir yer edinmek için absürtlük gibi unsurlara sıkıkla başvurmaktadır. Bu noktada, bazı reklamlar yalnızca belirli absürt unsurlar içermekle sınırlı kalırken, bazıları bir anlatım biçimi olarak tüm unsurlarıyla absürt anlatılar olabilmektedir. Bu çalışmada, absürt bir anlatı olarak değerlendirilen Eti Tutku reklamı dışında; Panda'nın reklam klişeleri ile alay ettiği parodisi, Falım'ın konuşan ve insanlara sakız dağıtan koç karakteri, Uludağ'ın "gazoz olma, efsane ol" söylemi, Eti Crax'ın "sürrealizm nedir" sorusuna yanıt aradığı reklamında kullandığı sahne tasarımı, Anadolu Sigorta reklamlarında sigortaya ihtiyaç duymayan insanların başına gelen olaylar gibi örnekler yakın zamanda yayınlanmış reklamlarda dikkat çeken absürt unsurlar olarak sıralanabilir.

Illgili literatür incelendiğinde, reklamda absürtlüğün edebi veya sanatsal bir anlatım biçimi olarak ya da reklam tasarımındaki görsel veya sözel vb. uyumsuz unsurlar olarak ele alındığı anlaşılmaktadır. Reklamda absürtlüğün etkilerini araştıran Arias-Bolzmann (1993, p. 3) absürtlüğü "izleyicilerin tuhaf, akıl dışı, mantıksız ve düzensiz olarak algıladıkları, uyumsuz biçimde sıralanmış görüntüler, kelimeler ve/ veya sesler" şeklinde tanımlamıştır. Absürtlüğün çeşitli mantıksız ilişkiler sonucunda oluşabileceğini ve doğası gereği mizahi olduğunu belirten Arias-Bolzmann et al. (2000, p. 36) bu mantıksız ilişkilerin kaynağı olarak da değerlendirilebilecek olan gerçeküstücülük, insanbiçimcilik, alegori ve abartıyı absürtlüğün farklı biçimleri olarak açıklamışlardır.

Reklamda absürtlüğü teatral bir çerçevede ele alan Stern (1990, p. 197) absürt tiyatronun, geleneksel gerçekçi tiyatroda sunulan düzenli, anlamlı ve değer yüklü dünyadan çok nedensel olmayan, belirsiz, anlamsız ve endişe verici olanı resmettiğini belirtir. Buna göre absürt oyun yazarı, dünyanın gerçekliğini sergileyerek bununla nasıl en iyi şekilde başa çıkılacağını izleyiciye bırakır. Bu noktada Stern'e göre, absürtlüğe başvuran bir marka da kendisinin ve dünyanın mükemmel olmadığını kabul ederek tüketicinin güven ve sempatisini kazanmayı amaçlar; belirsizlikle dolu bir dünyada kendisi için en iyi olanı seçmeyi tüketiciye bırakır. 
Stern'in (1990, p. 199) ayrıca belirttiği gibi, bir markanın reklamlarında absürtlüğü tercih etmesi, tüm pazarlama stratejisi ile ilişkili bir karar olarak değerlendirilebilir. Rakip markaların gerçekçi ve idealize vaatleri yerine tüketicilerle ortak bir dil oluşturma çabasındaki bu yaklaşım, başlı başına bir pazarlama stratejisi ya da marka konumlandırma kararı olarak da düşünülebilir. Bu yaklaşıma örnek olarak, Ergüven'in (2005) Diesel markası üzerine yaptığı inceleme dikkat çekicidir. Diesel, kendi kategorisindeki pek çok markanın sahiplendiği Amerikan değerleri ve yaşam tarzıyla alay ederek markaya özgü bir yaşam felsefesi yaratmıştır. Bu felsefe Diesel'in reklamlarına "for successful living" sloganıyla yansımaktadır. Diesel, tüketiciye bir cennet olarak sunulan tüketim kültürü değerlerinin, aslında ne kadar anlamsız ve gülünç olduğunu, reklamlarındaki "success" kavramını abartılı ve absürt bir tarzda işleyerek anlatmaktadır (Ergüven, 2005, p. 417).

Baysal, (2008, p. 42) absürdizmin aslında Batı kültürünün ve değerlerinin bir parodisini sunduğunu ve bu nedenle çoğunlukla mizahi olduğunu belirtmiştir. Bu bağlamda, kalıplaşmış algılar, vaatler, öyküler ya da görüntülerin parodisini sunan reklamlar da absürt olarak değerlendirilebilir. Stern (1992, p. 76) de absürdün kimi zaman bir tür parodi biçiminde olabileceğini belirtmiş ve Isuzu'nun "Joe Isuzu" karakterini kullanarak yarattığı reklamları buna örnek olarak vermiştir. Bu reklamlarda Joe, arabalar hakkında yalan olduğu açık biçimde belli olan vaatler sıralayarak rakiplerin gerçekçi araba reklamlarının bir parodisini yapmaktadır. Isuzu'nun yalanlar üzerine kurduğu bu strateji, Sprite'ın "acımasız gerçekler" kampanyasını çağrıştırmaktadır. Sprite, rakip markaların reklamlarında sunulan klişe ve idealize dünyanın parodisini acımasız gerçekler sunarak yapmaktadır. Uztuğ'un $(2008$, p. 130) da belirttiği gibi Sprite, marka imajlarından ve onların temsil ettiği yapay dünyadan sıkılan tüketicilere "imaj hiçbir şeydir, susuzluk her şey" sloganıyla farklı bir seçenek sunmaktadır.

Dikkatle incelendiğinde, felsefi arka planı ve bunun sanattaki yansımaları açısından absürdün, aslında dünyaya ve insanlığa dair son derece ciddi, hatta karamsar bir tablo çizdiği görülecektir. Bununla birlikte absürdün ortaya koyduğu uyumsuzluklarla dolu tablo kaçınılmaz biçimde gülünç ve dikkat çekici olacaktır. Bu noktada reklam yaratıılarının, absürtlüğü bir anlatım biçimi olarak alıp kendi amaçları doğrultusunda kullandığı düşünülebilir. Kimi zaman anlamlı ya da işlevsel bir yararı olmayan ürünlere dahi bir anlam katmak amacında olan reklamcılığın, yaşamın anlamsızlığı ve insanlığın absürt durumunu vurgulamayı tercih etmeyeceği kolaylıkla öngörülebilecektir. 


\section{AMAÇ VE YÖNTEM}

Reklamcılığın farklı bilim dallarıyla olduğu kadar, sanatla da yakından ilişkili olduğu düşüncesinden hareketle gerçekleştirilen bu araştırmada, reklamın dramaturjik çerçevede çözümlenmesine bir örnek sunmak ve çözümlenen reklam üzerinden, reklamda absürtlüğü teatral bir çerçevede değerlendirmek amaçlanmaktadır. Bu bağlamda, araştırma sorusu şu şekilde ifade edilebilir: Absürt dramaturji açısından "tema, eylem, sahne, karakter, dil ve ton" unsurları, çözümlenen reklamda nasıl karşılık bulmaktadır ve bu unsurlar açısından reklamın yarattığı anlam nasıl yorumlanabilir?

Bu soruya yanıt arayarak, absürt anlatının reklamdaki karşıığını dramaturjik unsurlar açısından ayrıntılı olarak ortaya koymak ve bu tarz reklamların yarattığı anlam ile birlikte, reklamcılıkta absürt strateji ve anlatım biçiminin kullanımına ilişkin çıkarımlar sunmak mümkün olacaktır.

Bu çalışma, nitel araştırma yaklaşımılla gerçekleştirilmiş betimsel bir çözümleme sunmaktadır. Araştırmada, tiyatro metinlerinin çözümlenmesi ve sahneye uygulanması uğraşı olan dramaturjiden yararlanılmış ve Stern'in (1990) dramaturjik unsurların absürt tiyatrodaki biçimlerini açıklayarak, bunları reklam örnekleriyle ilişkilendirdiği çalışması temel alınmıştır. Buna ek olarak, çözümleme için bir çerçeve oluşturmak amacıyla, absürt tiyatro anlayışı ve absürt dramaturjinin özellikleri konusunda farklı kaynaklardan yararlanılmıştır.

Çalışmada absürt tiyatroya ait unsurları yoğun olarak barındırdığı düşünülen Eti Tutku markasının bir televizyon reklamı, dramaturjik unsurlar açısından çözümlenmiştir. Eti Tutku'nun yakın zamandaki tüm reklamlarında absürt stratejiyi kullandığı söylenebilir. Markanın günümüzdeki reklam ajansı olan Güzel Sanatlar da reklamlarda "absürt ses tonunun da sağladığı alandan" yararlandıklarını açıklamışlardır ("Eti Tutku", n.d.). Markanın genellikle seriler halinde yayınladığı reklamların tümüne bu ses tonu hakim olsa da bu çalışmada bir örnek olay olarak, dramaturjik yaklaşımın tüm unsurları açısından absürt anlatımı karşılayan bir reklam filmi olduğu düşünülerek, 'fal' temalı reklam filmi araştırma nesnesi olarak ele alınmıştır. 


\section{BULGULAR}

Görsel 1'de temsili bir storyboard ile görsel olarak aktarılmaya çalışılan reklam filmi, üzerinde "Eti Tutku Müşteri Hizmetleri" yazılı bir kapının iki yana açılmasıyla başlar. Tiyatro perdesinin açılma anını da çağrıştıran bu kapı, marka ve müşteri arasında gelişen olayları resmeden bir reklam anlatısına izleyiciyi hazırlar. Diyaloglardan anlaşıldığı üzere, bir müşteri Tutku kurabiyenin akışkan kreması ile fal baktırmak üzere buraya gelmiştir. Markanın bir çalışanı olduğu anlaşılan kişi, kadının falına bakar. Kadın ve onun hemen yanındaki koltukta oturan kim ya da ne oldukları anlaşılmayan tuhaf görünümlü iki karakter falcının söylediklerine, şaşkın ve anlamsız tepkiler verirler. Reklam, ürünün "enfes akışkan kreması" gibi özelliklerinin anlatılmasıyla son bulur. Söz konusu reklam aşağıda, absürt dramaturji açısından; tema, eylem, sahne, karakter, dil ve ton başlıkları altında çözümlenmiştir.

\section{Tema}

Bir metnin altında yatan ana fikir, o metinle anlatılmak istenen asıl düşünce, tema olarak adlandırılır. Absürt tiyatro eserlerinin teması, genellikle insanın ve evrenin uyumsuzluğu, iletişimsizlik, hayatın anlamsızlığı ve büyük ideallerin değersizliği gibi düşünceler etrafında şekillenir. Absürt stratejiyi benimseyen bir markanın da bu doğrultuda tüketiciye büyük vaatler, değerler ve idealize edilmiş ürün sunumları yerine; daha basit, hatta kimi zaman gerçek hayatta belirli bir karşılı̆ı olmayan mesajlar sunması olasıdır.

Bu noktada, Eti Tutku'nun tek vaadi olan akışkan kremasını gerçekte hiçbir karşılığı olmayan, hatta anlamsız olarak değerlendirilebilecek biçimde kahve falı bakma eylemiyle resmetmesi dikkat çekicidir. Reklamın sonunda dış sesin "Tutku kurabiyenin enfes akışkan kremasıyla kendinizi hayatın akışına bırakın” önerisi de ürün özellikleri ile tüketiciyi yakalamaya çalışmaktan çok, kelime oyununa dayalı alaycı bir tavır gibi görünmektedir. Sonuç olarak markanın, hızlı tüketim ürünü olarak değerlendirilebilecek kremalı bir kurabiyeden ibaret olan ürünü ile eşsiz bir tat, müthiş bir doyum ya da aynı kategorideki pek çok markanın yaptığı gibi mutluluk benzeri büyük bir ideali satmaya çalışmak yerine, bu tarz vaatlerden sıkılmış olan tüketiciye daha samimi gelebilecek bir temayla yaklaştığı söylenebilir. 
Tema unsuru, tek başına ifade ettiği anlamın yanı sıra, anlatının diğer unsurları üzerinde de etkili olur. Bu noktada İpşiroğlu'nun (1996) absürt oyunlarda kullanılan temalar olarak açıkladığı "toplum yaşamı ve ortamı ile birey arasındaki uyumsuzluk", "insan ilişkilerindeki uyumsuzluk" ve "yaşanılan zamanla uyumsuzluk" temaları, anlatının karakter, dil ve eylem gibi diğer unsurları üzerinde belirleyici olmaktadır. Söz konusu bu temaların ne anlam ifade ettiği ve anlatı üzerindeki etkileri ilgili unsurlar açısından aşağıda ayrıca tartışımaktadır.

\section{Eylem}

Eylem, bir anlatıda birbiriyle ilişkili olaylar dizisini ifade eder. Klasik anlatılarda birbiri ile nedensel ilişki içerisinde olan ve anlamlı bir sonuca ulaşan olaylar resmedilir. Absürt tiyatro eserlerinde ise hayatın anlamsızlığını yansıtacak biçimde, amaçsız ve anlamsız olaylar birbiri ardına belirli bir neden sonuç ilişkisi olmaksızın gelebilir (Stern, 1990, p. 193).

Eti Tutku reklamına bakıldığında, asıl eylemin kurabiyeden kahve falı bakmak gibi anlamsız ve amaçsız bir eylem olduğu görülecektir. Karakterlerin neden böyle bir eylemde bulundukları ya da bunun sonucunda neye varıldığı da tamamen belirsizdir. Fal bakan kişi ve müşteri olduğu anlaşılan kadının sanki bir televizyon programındaymış gibi kameralara bakarak hareket etmesi de canlandırılan eylemin bir oyun mu yoksa gerçek mi olduğu konusunda izleyeni şüpheye düşürmektedir. Tüm bu anlamsız olaylar dizisi içerisinde anlaşılan tek şey Tutku kurabiyenin kremasının akışkan bir kıvamda olduğudur. Bu aynı zamanda markanın tüketicilere sunduğu en önemli vaadidir.

İpşiroğlu'nun (1996, p. 59) absürt oyunlarda kullanılan temalardan biri olarak açıkladığı "yaşanılan zamanla uyumsuzluk" teması insanın kendisini bekleyen kaçınılmaz sona, yani ölüme kadar geçirdiği süredeki tüm çabalarının boşunalığını temel alır. Bu nedenle, absürt oyunlarda çoğu zaman insanın hayattaki amaçsız eylemleri resmedilir. Örneğin, Pinter'ın Git Gel Dolabı oyunundaki iki karakter, çay içerek, oyun oynayarak, havadan sudan konuşarak zaman öldürmekle meşgulken, kendilerine verilen emirleri de hiç düşünmeden yerine getirmektedir (ipşiroğlu, 1996, p. 38).

Tutku reklamındaki asıl eylem olan fal ritüelini kenardan izleyen ve kim oldukları bilinmeyen iki tuhaf karakter de herhangi bir amacı olmadığı sezilen anlamsız 
eylemlerde bulunmaktadırlar. Kendilerine bir kahve gibi servis edilmiş olan kurabiyeyi içindeki kremayı içerek tüketen bu karakterler, birer robot gibi davranarak, eş zamanlı, mekanik ve herhangi bir amaca hizmet etmeyen eylemleriyle, yalnızca belirli bir zamanda belirli bir yerde bulunarak anlamsız hayatlarının herhangi bir bölümünü tüketmekle meşgul oldukları izlenimi vermektedirler.

Geleneksel tiyatroda, dil aracılığıyla mantık kurallarına uygun bir biçimde düzenlenmiş; başı, düğüm noktası ve sonu olan bir olay örgüsü vardır. Sahnede bu olaylar gerçekmiş gibi canlandırılmaya çalışılır (İpşiroğlu, 1996, p. 16). Absürt anlatımın en belirgin özelliklerinden biri ise geleneksel olay örgüsündeki gelişmeler ve nedene bağlı sonuç mantığına karşı olmasıdır. Şener'in (1998, p. 303) de belirttiği gibi, absürt tiyatroda oyunun tutarlı bir olay gelişimini gösteren öyküsü yoktur. Akla yakın bir amacı olmadığı sezilen öykü, kişilerin iç karmaşasını açıklayan uzun bir serimdir. Beckett'in Godot'yu Beklerken (1963) adlı oyunu buna verilebilecek en güzel örneklerden biridir. Oyunun iki baş karakteri, Godot adında kim olduğu bilinmez birini beklemektedirler, oyunun sonunda Godot gelmez, ama onlar beklemeye devam edeceklerdir. Tutku reklamının öyküsü de geleneksel anlatıdaki olay gelişiminden uzak bir görünüm sergilemektedir. Reklamın her ne kadar belirgin bir başlangıcı ve bitişi olsa da öykünün herhangi bir düğüm noktası, olaylar arasında mantıklı bir neden sonuç ilişkisi, hatta sunulan olayların belirgin bir anlamı ve yaşananların sonucu olarak sunulan bir çıktı da yoktur.

\section{Sahne}

Sahne ile kastedilen anlatıdaki olayların gerçekleştiği mekandır. Bu tanım, mekanın tasarımını ve bu tasarım içerisinde bulunan unsurlarla yaratılan fiziki ve duygusal ortamı kapsamaktadır. Absürt sahne tasarımları, genellikle neyin gerçek ya da sıradan olduğu konusunda izleyeni şüpheye düşürecek ve gerçekliğin sorgulanmasına neden olacak bir yapıdadır (Stern, 1990, p. 194). Bu amaçla, birbirleriyle uyumsuz ve neden bir arada oldukları belirsiz unsurların kullanımı olasıdır. Absürt oyun yazarları sahnede uyumsuzluk yaratmak için doğada karşılığı bulunmayan imgeler de kullanırlar. Bilinen gerçeğe benzemeyen, fakat kendi ölçüleri içinde tutarlı olan ve bir anlam ifade eden bir düzen kurarlar. Sahnenin çok boyutlu ortamı, ışığın, sesin, hareketin, görüntünün ve dilin eşzamanlı kullanılması ile yaratılan imge dokusu bir bütünlük taşır (Şener, 1998, p. 305). Ionesco'nun Amedee oyunundaki giderek büyüyen ve odaya sığmaz hale gelen ayak imgesi ile evin içinde türeyen 
mantarlar ya da Beckett'in Mutlu Günler oyunundaki beline kadar toprağa gömülü kadın sözü edilen bu imgelere örnek olarak gösterilmektedir (Aydemir , 2003, p. 25).

Eti Tutku reklamındaki sahne tasarımı incelendiğinde, kapısındaki yazıdan müşteri hizmetleri birimi olduğu anlaşılan mekanın, uyumsuz bir dekorla donatılmış, günlük hayatta karşılaşma olasılığımız çok düşük olan, tuhaf ve gerçek dışı bir mekan olduğu görülür. Sahne tasarımı, tıpkı absürt tiyatroda olduğu gibi uyumsuzdur, çünkü ilk bakışta bir uzay gemisi ya da boş bir stüdyoyu andıran ortam, adeta bir evin misafir odası gibi döşenmiştir. Ortamdaki halı, sehpa, örtü, lamba ve koltuk gibi eşyalar eski moda ya da geleneksel olarak adlandırabileceğimiz tarzdadır. Bu tasarım, geleneksel bir ritüel olan kahve falı bakma eylemiyle uyumlu görünse de bir tür stüdyo ya da müşteri hizmetleri birimi olduğu düşünülen ortamla uyumsuz bir görüntü sergilemektedir.

Reklamın ticari bir iletişim biçimi olduğu düşünüldüğünde, söz konusu reklam filminin dikkat çekmek, hatırlanmak, marka kimliği ya da ürün özelliği gibi mesajları tüketicilerle buluşturmak ve sonuçta ürünün satın alınmasına katkı sağlamak gibi amaçları olması beklenir. Bu noktada, Tutku reklamındaki sahne tasarımının bu amaçlar için gerekli unsurları, absürt tasarıma uygun bir biçimde sunduğu gözlemlenmektedir. Sahnenin tümüne bakıldığında, karakterlerin bulunduğu ve asıl olayların gerçekleştiği mekanın, geniş bir boş alanın ortasında, daha sınırlı bir alana yerleştirilmiş olduğu görülür. Bu durum özellikle geniş açıda verilen ilk çekimde, sahne tasarımının alışılmışın dışında bir görüntü sunarak dikkat çekmesini sağlamaktadır. Ayrıca, akışkan kremasının yanı sıra markanın önemli bir ayırıcı özelliği olan mozaik kurabiye deseni, sahnedeki farklı nesnelerin üzerinde dikkat çekmektedir. Sehpa örtüsünden kırlente, duvardaki havalandırma aleti benzeri dönen nesnelerden, oyuncuların şakaklarına kadar beklenmedik pek çok yerde göze çarpan bu desen, hem ürünü temsil etmekte hem de sahne tasarımındaki absürtlüğe katkı sağlamaktadır.

\section{Karakter}

Yazar tarafından yaratılan kişi ya da kişiler genellikle kahraman ya da karakter olarak anılır. Gerçekçi ya da klasik olarak adlandırabileceğimiz tiyatroda resmedilen fiziksel, duygusal ve sosyal özellikleri iyi kurgulanmış, inandırıc karakterlerin aksine; absürt tiyatro karakterleri genellikle tek boyutlu, özellikleri belirsiz ya da anlaşılmaz karakterlerdir. 
Tutku reklamındaki karakterlere bakıldığında öncelikle, marka tarafında oldukları anlaşılan üniformalı karakterlerle müşteri olduğu anlaşılan kadın arasındaki uyumsuzluk dikkat çekmektedir. Karakterler tek tek incelendiğinde de her birinin; görünüş, konuşma ve davranış biçimleriyle yukarıda tanımlanan absürt karakter özelliklerine sahip oldukları görülmektedir. Özellikle, birbirinin kopyası gibi görünen kadın ve erkek karakterler adeta absürt bir tiyatro oyunundan alınmış gibidirler. Şakaklarındaki kurabiye görseli ile otomobil çarpışma testlerindeki cansız mankenleri andıran bu karakterler, abartılı ve anlamsız davranışlar sergileyerek anlatıdaki belirsizlik algısına katkıda bulunmaktadır.

İpşiroğlu (1996, p. 24) "toplum yaşamı ve ortamı ile birey arasındaki uyumsuzluk" temasıyla ilişkili olarak, lonesco'nun çoğunluğa uyarak adeta akıntıya kapılmış bir görünümle betimlediği "kitle insanı" olgusuna dikkat çekmektedir. Absürt oyunların pek çoğunda, kişiliği olan bireyin karşıtı olarak değerlendirilen kitle insanının trajikomik dünyası anlatılır. Bu temayı işleyen oyunlarda karakterler, uyumsuzluğa direnmek yerine onu kabullenmiş ve normal karşılayan karakterler olarak karşımıza çıkarlar. lonesco'nun (2000b) umarsızca birer gergedana dönüşen karakterleri bu duruma verilecek en güzel örneklerden biridir.

Tutku reklamındaki karakterler incelendiğinde de ne falcı rolündeki müşteri temsilcisinin kurabiye ile kahve falı baktırmaya gelen kadını, ne müşteri rolündeki kadının yaşanan tüm anlamsız olayları yadırgadığı söylenemez. Diğer iki karakterin yaşananlara verdiği tepkilere de bakılırsa, reklamdaki tüm karakterlerin gerçekle uyumsuz ve aslında hiçbir anlam ifade etmeyen eylemleri sanki çok anlamlıymış gibi kabul ettikleri görülmektedir.

Absürt tiyatroda oyun kişilerinin özellikleri gibi bazen adları da belli değildir (Şener, 1998, p. 303) ya da bu kişilerin, kalabalıklar arasındaki herhangi biri olabileceği algısını yaratmak için toplum içerisinde yaygın olarak kullanılan isimler tercih edilir (Acarlıoğlu, 2003, p. 35). Ionesco'nun (2000a) Kel şarkıcı oyunundaki Bay ve Bayan Smith ile Bay ve Bayan Martin isimleri buna verilebilecek örneklerdir.

Söz konusu, genellikle kısa süreli yapımlar olan televizyon reklam filmleri olduğunda, özel bir anlam ifade etmediği sürece gerek absürt gerek absürt olmayan reklamlarda karakter isimleri çoğu zaman belirsizdir. Tutku reklamında ise markayı temsil eden karakterlerin isimleri bilinmezken, müşteri olduğu anlaşılan kadın, 
seyirciye "Libadiye'den Birsen Eksiktin" ismiyle tanıtılır. Bu isim, çok açık bir biçimde anlaşılacağı gibi, kelime oyununa dayalı alaycı ve gülünç bir isimdir. Bu noktada karakterin gerçek isminin aslında bu olmadığı, hatta gerçek bir isme dahi ihtiyacı olmayan absürt bir karakter olarak resmedildiği düşünülebilir. Bu reklamın, seri biçimde yayınlanan diğer örneklerinde yer alan "Muğla'dan Sıtkı Sıyrılmış", "Antalya'dan Ayşegül Tatilde" gibi isimler de aynı absürt tavırla belirlenmiş, gerçek olmadığı açıkça belli olan, toplumdaki belirli bir kimliği ya da grubu temsil etmeyen, bir başka deyişle içimizden herhangi biri izlenimini veren isimler olarak değerlendirilebilir.

Karakter söz konusu olduğunda, göz önünde bulundurulması gereken bir diğer unsur da bu karakterlerin canlandırılması, yani oyunculuktur. Absürt tiyatroda, gerçekçi oyunculuktan kaçınmak için, abartmaya, doğal olmayan oyunculuğa, karikatürleştirmeye başvurulur (Şener, 1998, p. 303). Tutku reklamındaki oyunculukların da absürt anlatıma uygun olarak, abartılı ve yapmacık bir tarzda olduğu görülmektedir. Özellikle, test mankenine benzeyen iki karakterin mekanik ve abartılı davranışları, karikatürize bir oyunculuk biçimi sergilemektedir.

\section{Dil}

Dil, genel olarak kelimelerin ifade ettiği her şeydir (Stern, 1990, p. 195). Absürt düşünceyi benimseyen yazarlara göre, dil artık iletişim kurmaya değil, insanlar arasındaki iletişimsizliği maskelemeye yaramaktadır. İnsanlar klişeleşmiş selamlaşma biçimlerini, sohbet konularını kullanarak aralarında asla var olamayan bir ilişkiyi varmış gibi göstermeye çalışmakta, dahası buna kendileri de inanmayı istemektedirler (Güllü, 1997, p. 369). Bu anlayışın bir yansıması olarak, absürt oyunlarda konuşma bir anlaşma aracı değil, anlamsız bir gevezeliktir. Söz ile anlam birbiriyle çelişir. Bu yüzden konuşmalar anlamı açıklamaz, gizler. Gerçek anlamı boşaltılmış konuşma, yalan ve düzmece bir gerçeğe işaret eder (Şener, 1998, p. 300). Ionesco'nun (2000a) Kel Şarkıcı oyunu bu duruma da bir örnek olarak gösterilebilir. Yazarın "dil trajedisi" olarak adlandırdığı ve kitapla İngilizce öğrenirken karşılaştığı günlük bayağı konuşmalardan esinlenerek yazdığı bu oyun birbirinden kopuk rastgele cümlelerle doludur (Acarlıoğlu, 2003, p. 12). Özetle, absürt tiyatro karakterlerinden anlamlı diyaloglar ve tutarlı ifadeler kullanmaları beklenmez. Bu tarzda kullanılan dilin genellikle değersiz, çoğu zaman tutarsız, ne anlama geldiği çok da açık olmayan, hatta bazen de anlamsız bir yapıda olduğu söylenebilir (Stern, 1990, p. 195). 
Tutku reklamındaki ilk replik olan "Libadiye'den Birsen Eksiktin, kapatmış tutkusunu gelmiş" ifadesi ne anlama geldiği belirsiz, hatta anlamsız bir söz olarak dikkat çekmektedir. Reklamın devamında aynı karakterin, müşterinin falına bakarak, "sizin içiniz akışmış" şeklindeki yorumu ve kadının buna cevap olarak"ayy bak görüyor musun içim akışmış" tepkisi de izleyici açısından pek bir anlam ifade etmeyen ve olay gelişimine katkı sağlıyor gibi görünmeyen bir absürt diyalog örneği olarak değerlendirilebilir. Burada absürt dil kullanımı açısından dikkat çeken önemli bir nokta da söz konusu anlamsız diyaloğu karakterlerin hiç yadırgamıyor oluşu ve bu içeriğe, sanki çok önemli bir konuda konuşuluyormuş gibi tepkiler vermeleridir. Bu noktada reklamdaki karakterlerin sözleri ve üretilen anlam arasındaki çelişkinin absürt oyunlardakine benzer bir anlaşılmazlık ve belirsizlik yarattığı görülmektedir. Ayrıca yukarıda karakter unsuru açısından değinilen karakter isimleri, dil açısından da absürt özellikler göstermektedir. Birer kelime oyunu olduğu anlaşılan ve gerçek olmadıkları belli olan karakter adları da anlatıdaki anlamın belirsizleşmesine ve anlaşıımaz olmasına katkı sağlamaktadır.

Tiyatro açısından dil, monolog ve diyaloglara ek olarak, jest, mimik ve ses kullanımı gibi unsurları da kapsamaktadır. Bu noktada konuşmalar kadar, sessizlik ve mim gibi unsurların kullanımı da dil kapsamında değerlendirilir. Dilin işlevini ve anlamını yitirdiğini düşünen ve eserlerinde dili değersizleştirerek kullanan absürt yazarlar da kimi zaman oyunlarında soytarı benzeri ya da sessiz karakterlerle birlikte mim unsuruna da başvurmaktadırlar (Stern, 1990, p. 196). Bu bağlamda reklamda, yalnızca jest ve mimikleriyle olaya dahil olan tamamen sessiz iki karakterin, reklamın genelindeki absürt dile uygun olarak anlatıya katkı sağladıkları söylenebilir.

\section{Ton}

Tiyatro açısından bakıldığında ton, yazarın işlediği konuya ve izleyicisine karşı takındığı tutum olarak tanımlanabilir. Pazarlama iletişimi açısından ton ile kastedilen ise markanın kendine, mesajına ve tüketicisine yaklaşımıdır. Absürt yaklaşım, hayatın anlamsız, insanın da mantıksız, tutarsız ve uyumsuz olduğunu savunur. Absürt eserlerde bu durumu izleyicinin yüzüne vuran alaycı ve mizahi bir yaklaşım söz konusudur. Bu yaklaşım, evrenin kendisini kozmik bir şaka olarak kabul eder; hayattaki anlam arayışı ve insanlığa sunulan büyük vaatler ile alay eder. Bu doğrultuda, absürt stratejiyi benimseyen bir marka, reklamların çoğunluğuna hakim olan idealize edilmiş vaatler ve yaşam tarzları sunmak yerine, kendisinin de tıpkı dünyanın geri kalanı gibi 
mükemmel olmadığını kabul ederek, tüketicinin güven ve sempatisini kazanmayı amaçlar (Stern, 1990).

Tutku reklamı bu açıdan incelendiğinde, reklam filminin absürt tiyatroda karşılaşılan alaycı ve mizahi tona sahip olduğu söylenebilir. Marka, bu reklam ile her şeyden önce kendisini ve ürününü alay ve mizah konusu haline getirmektedir. Reklamda müşteri ilişkileri birimi olarak gösterilen tuhaf ortamda, markayı temsil eden absürt karakterlerin anlamsız konuşma ve davranışları, markayı akıl ve mantıktan uzak, adeta bir tür "delilik" durumuyla ilişkilendirmektedir. Pek çok ürün reklamında olduğu gibi Tutku reklamında da ürün özellikleri çekici bir tarzda resmedilmektedir. Öte yandan, ürünün en önemli özelliği olan akışkan krema, ürünün gerçek faydasıyla hiçbir ilgisi olmayan fal bakma eylemiyle resmedilmektedir. Dolayısıyla markanın aslında tek vaadi olan akışkan kremasıyla da bir biçimde alay ettiği söylenebilir. Reklamda müşteriyi temsil eden karakterin de reklamın geneline hakim olan alaycı tavırdan payına düşeni aldığı sezilmektedir. Markanın müşterileri, Birsen Eksiktin adıyla adeta varlığı sorgulanan ve kurabiye ile fal baktırmak üzere markaya başvuran biri olarak temsil edilmektedir. Ayrıca absürt, Batı dünyası ve değerlerinin parodisi olarak da kabul edilir. Bu nedenle, absürt eserlerde sıklıkla parodi olarak değerlendirilebilecek göndermelere rastlanır. Tutku reklamı da yayınlandığı toplumda yaygın olan kahve falı bakma ritüeli ya da gün adı verilen ev davetlerinin bir parodisi gibidir. Hatta reklamın, gündüz kuşağı TV programlarının parodisi olduğu da düşünülebilir. Bir başka açıdan bakıldığında, reklamda parodi konusu yapılanlardan biri de müşteri memnuniyetini sağlamak amacıyla pek çok markanın önem verdiği müşteri ilişkileri birimleri ve bu birimler tarafından sunulan hizmetler olarak değerlendirilebilir.

Aydemir'e (2003, p. 25) göre, çağımız insanının açıklanması, anlaşıması zor gerçeklerle karşı karşıya bulunması, bir başka deyişle insan ile insan doğasına aykırı olan dünya arasındaki uyuşmazlık ve çelişkiler absürt tiyatronun, groteske başvurmasını gerekli kılmıştır. Grotesk ise gerçek ve mantıksal olanla bağdaşmayan, abartılı, tuhaf ve şaşırtıcı durumlardan alışılmadık gülünçlükler yaratan biçim olarak tanımlanmaktadır. Şener (1998, p. 304) de absürt oyunlarda grotesk ile birlikte; alay etme, taşlama, aşağılama yöntemlerine başvurulduğunu belirtir. Böylece, insanın şaşkınlığı, budalalığı, korkaklığı ve güvenilmez oluşu sergilenir. Bu durum, özünde trajik, fakat aynı zamanda özellikle de komik olanı yansıtır. Güllü'nün (1997, p. 363) de belirttiği gibi, absürt oyunlarda mizah vazgeçilmez bir unsurdur ve akımın sanat 
anlayışının merkezine oturur. Bu noktada, Tutku reklamının tonu da gerçekçilikten çok groteske; ciddiyetten çok alaycılığa; markayı, ürünü ve müşteriyi yüceltmekten çok taşlamaya; akılcılıktan çok saçmalamaya ve sonuç olarak mizaha daha yakın bir tavır olarak değerlendirilebilir.

\title{
TARTIŞMA VE SONUÇ
}

İpşiroğlu (1996, p. 18) absürt tiyatronun önemli yazarlarından biri olan Eugene lonesco'nun tiyatrosunu şu şekilde tarif eder:

\begin{abstract}
...Havalarda uçuşan insanlar, eşya yığınlarının arasında ezilip yitenler, insanlıktan çıkıp gergedan biçimine girenler, hiç beklenmedik bir anda biçim değiştirip tuhaf görüntülere dönüşen tipler canlanıyor gözümüzün önünde. Sanki dev bir büyüteç ardından yansıtılıyor yaşam bize. Düşler, duygular, zevksizlik ve saçmalığa dönüşüyor; dil de yıpranıyor, parçalanıyor, tek tük havada uçuşan sözcükler, sülük gibi yapışıp kalıyorlar insana.
\end{abstract}

Burada tarif edilen dünyanın, absürt reklamlar açısından da geçerli olduğu düşünülebilir. Absürt reklamlarda, gerçeküstü ya da uyumsuz sahne tasarımları, karakterler ve olaylar, yaşamın ve insanın absürtlüğünü ortaya koymak için olmasa da en azından reklama ve markaya dikkat çekmek ve akılda kalmak için sıklıkla kullanılmaktadır. Reklamların çoğuna hakim olan idealize edilmiş yaşam biçimleri, ürün sunumları vb. absürt reklamlarda alay konusu haline gelmektedir. Her ne kadar, tüketici için anlamı olan bir vaat yarar bileşenini sunma kaygısı her zaman var olsa da absürt reklamlarda kullanılan dil, zaman zaman anlamsız ya da en azından ne demek istediği tam olarak belli olmayan bir biçimde karşımıza çıkmaktadır.

Bu çalışmada, reklamlarda sıklıkla kullanılan absürt anlatım biçimi, absürt kavramının çok özel bir anlam ifade ettiği tiyatro sanatı açısından ele alınmıştır. Bu açıdan çalışma, reklamın sanatla ilişkili boyutundan hareketle yapılandırılmıştır. Reklamda absürtlük konusundan bağımsız olarak düşünüldüğünde de tiyatronun özellikle televizyon ya da daha genel anlamda film olarak adlandırabileceğimiz reklam biçimiyle benzer bir görsel işitsel dil açısından ortaklığı olduğu düşünülmektedir. Çalışmada, bu ortak noktadan yola çıkılmış ve Stern'in (1990) önerdiği dramaturjik çerçeveden yararlanılarak Eti Tutku markasının bir reklam filmi çözümlenmiştir. 
Yukarıda ayrıntılı olarak açıklandığı gibi, çözümlenen Eti Tutku reklamının, tema, eylem, sahne, karakter, dil ve ton unsurlarının her biri açısından absürt tiyatro eserleriyle benzer bir anlatım biçimine sahip olduğu düşünülmektedir. Eti Tutku, neredeyse diğer tüm reklamlarında olduğu gibi bu reklamında da en önemli ayırt edici özelliği olan akışkan kremasını vurgulamak adına, markanın kendisine, reklam mesajına ve hedef kitlesi olan müşterisine absürt ses tonuyla yaklaşmaktadır. Marka, günümüzde pek çok markanın sahiplenmeye çalıştığı; mutluluk, güven, özgürlük ya da en iyisi olma gibi ideal değerler yerine, bu değerlerle adeta alay ederek hedef kitlesine, absürt ve anlamı belirsizliklerle dolu bir mesaj iletmektedir. Bu noktada, ticari bir markanın değersizlik, anlamsızlık ya da absürtlük gibi bir temayı sahiplenmesi ilk bakışta tuhaf görünmektedir, fakat günümüzün reklam kirliliği ortamında, idealize ve birbirine benzer vaatlerden sıkılmış bir tüketiciyi yakalamak için bunun doğru tercih olabileceği düşünülmektedir.

Aydemir'e (2003, p. 21) göre, absürt oyun yazarları insanlığın absürt durumu ve bunun yarattığı saçmalık, anlamsızlık, iletişimsizlik, yabancılaşma gibi sorunları ortaya koymakla birlikte, bunlara herhangi bir çözüm önermemektedirler. Oysa tüketiciye bir çözüm önerisi, bir vaat sunma amacındaki reklamlar için bu durum farklıdır. Bu açıdan Tutku reklamına bakıldığında, markanın yaşanan tüm absürt durum içerisinde bir çözüm olarak kendi ürününü işaret ettiği düşünülebilir. "Tutku kurabiyenin enfes akışkan kremasıyla kendinizi hayatın akışına bırakın; fala inanmayın, Tutkusuz kalmayın." önerisi, fal baktırmak üzere gelen müşteri üzerinden tüm tüketicilere, üstü kapalı bir biçimde hayata ya da onun getirdiklerine boş vermeye ve ürünün vereceği hazzı paylaşmaya bir davet olarak kabul edilebilir.

Çözüm sunma konusunda Tutku reklamı açısından ilginç olan bir durum da bu reklam serisinde müşterilerden gelen sorunlara Tutku Müşteri Hizmetlerinin sunduğu çözümlerin anlatılıyor olmasıdır. Bu noktada, serinin tüm reklamlarına bakıldığında müşterilerin sorunları olarak sunulan; geleceği öğrenme kaygısı, kurabiyenin deseninden hipnotize olma, kremanın sürekli aşağı doğru akması gibi durumların aslında gerçek olmadığı, hatta isimlerine bakılırsa sorunlarını ileten müşterilerin dahi gerçek olmadığı sezilmektedir. Bu noktada markanın, bir reklam formatı olan problem çözme yaklaşımıyla alay ederek, reklam dünyasına dair bir klişenin de parodisini yaptığı iddia edilebilir.

Reklamda absürtlük söz konusu olduğunda gerçeklik konusuna bir parantez açmak gerekecektir. Daha önce de değinildiği gibi absürt anlatım biçimi, neyin gerçek 
olup olmadığı konusunda izleyeni şüpheye düşürmekte ve ciddiyetten uzak yapısıyla belirsiz bir anlam üretmektedir. Bu açıdan absürt stratejinin markalar için bazı risklerle birlikte fırsatlar da sunduğu düşünülebilir. Eti Tutku örneği üzerinden değerlendirmek gerekirse, reklamdaki absürt anlatım, ürünün en önemli özelliği olan akışkan kremasına ilişkin vaadin gerçekliğinin sorgulanmasına neden olabilecektir. Bu noktada markanın, farklı bir strateji izleyerek kremasının ne kadar lezzetli ve akışkan olduğunu reklamlarında kanıtlamaya çalışabileceği de akla gelmektedir. Fakat absürt anlatım, markanın bilinçli olarak başvurduğu bir yol, bir tercihtir. Bu anlatım sayesinde ürün özelliği olarak sunulan vaatler tüketicileri tatmin etmese dahi ortada ciddi bir sorun olmadığı iddia edilebilir. Absürt stratejiyi benimseyen marka, zaten kendisinin de dünyanın geri kalanı gibi mükemmel olmadığını; markanın, ürünün ya da reklamın çok da ciddiye alınması gerekmediğini ima etmektedir.

Bilindiği gibi reklamcılık, markalar için hikâye anlatmanın araçlarından biridir. Hikâye anlatımı ise insanlığın en eski ve etkili iletişim yollarından biri olarak kabul edilir. Tiyatro da bir hikâyeyi, olayı ya da durumu canlandırarak kendine özgü yaklaşım ve anlatım biçimleriyle etkili bir iletişim aracıdır. Hikâye anlatımı ve tiyatronun tüm iletişim biçimleriyle olduğu gibi reklamla da ortaklığı bu açıdan anlamlı bir zemine oturmaktadır.

Absürt anlatım biçimi de hikâye anlatım tarzlarından biri olarak değerlendirilebilir; fakat anlatı yapısı açısından olduğu gibi, etkileri bakımından da absürdün, diğer hikâye anlatım tarzlarından ayrıldığı düşünülmektedir. Gerek reklamda (Boller \& Olson, 1991) gerek diğer ikna amaçlı metinlerde (De Graaf, Hoeken, Sanders, \& Beentjes 2012) ya da medya içeriklerinde (Cohen, 2001) hikâyelerin etki mekanizmalarından biri olarak karakterle özdeşleşme olgusuna dikkat çekilmektedir. Genel olarak izleyicinin hikâyedeki bir karakterle özdeşleşmesi durumunda hikâyenin ikna edici etkisinin artacağı düşünülmektedir. Fakat, anlamsız konuşma ve eylemleriyle dikkat çeken, genellikle iyi yapılandırılmamış ve gerçeklikten uzak absürt karakterler ile özdeşleşmek her zaman mümkün olmamaktadır. Şener'in (1998, p. 302) de belirttiği gibi, absürt tiyatroda seyircinin sahnedeki oyun kişileri ile özdeşleşmesi neredeyse olanaksızdır. Bu durum, Tutku reklamındaki karakterler için de geçerlidir. Reklamda doğrudan müşteriyi, yani izleyiciyi temsil eden bir karakter olmasına rağmen, bu karakterle izleyicinin görünüş, konuşma, değerler vb. açısından özdeşleşmesi çok olası görünmemektedir. Ne bir tüketici olarak sorunu, ne marka ve ürün ile kurduğu ilişki ne de adı ve kişilik özellikleri gerçekçi görünmeyen bu karakter 
ile özdeşleşip olaylara onun gözünden bakmak yerine, izleyicinin daha uzak ve tarafsız bir açıdan reklamda olup bitenleri izlediği düşünülebilir. Absürt anlatı, özdeşleşme dışındaki mekanizmalar aracılığıyla etkisini gerçekleştirmektedir.

Reklamda absürtlüğün etkilerini araştıran çalışmalarda (Arias-Bolzmann et al., 2000; Gelbrich et al., 2012; Yıldız \& Uztuğ, 2017) absürtlük içermeyen reklamlarla karşılaştırıldığında, absürt unsurlar içeren reklamların dikkat, hatırlama ve tutum gibi değişkenler üzerinde genel olarak olumlu etkileri olduğu gözlemlenmiştir. İzleyiciye farklı ve alışılmadık gelen absürt unsurlar, diğer içeriklere kıyasla daha fazla dikkat çekmekte; bu yeni içeriği, alışılmış olana göre daha fazla işleyen insan zihninde bu içeriğe ilişkin daha fazla unsur hatırlanmakta ve genellikle daha sıradışı, ilgi çekici ve eğlenceli olan absürt reklama yönelik tutum da daha olumlu olmaktadır. Absürt anlatının tüm unsurları açısından, absürt bir reklam olarak örnek gösterilebilecek olan Tutku reklamı ve benzeri reklamların izleyiciler üzerinde nasıl bir etki yarattığının araştırılması bu alana katkı sağlayacaktır.

Bu çalışma sonucunda, Eti Tutku markasının burada açıklanan absürt stratejiyi benimsediği iddia edilebilir. Bununla birlikte, çözümleme yapılırken verilen absürt oyun örnekleri ile reklam arasında doğrudan bir benzerlik ilişkisi olduğu ya da reklamın bazı absürt oyunlara göndermeler yaptığı söylenemez. Şüphesiz, bir reklamı yalnızca izleyiciye sunulan görünümü üzerinden çözümlemek, söz konusu reklamın üretim süreci ya da markanın amacı ve stratejisine dair kesin bilgiler sunmayacaktır. İncelenen reklamda absürt unsurların kullanımı ve absürt yaklaşımın izleri son derece görünür olsa da markanın bu reklam ile hedeflediği nedir, reklam yaratıcılarının ürettikleri bu içeriğe olan yaklaşımı nasıldır ya da reklamın yaratım sürecinde absürt unsurların kullanımına burada çözümlendiği biçimde dikkat edilmiş midir gibi sorular yanıt beklemektedir. Bu noktada, burada dikkat çekilen yaklaşımının temel bir eksikliği olarak işaret edilen bu boşluğu doldurmak adına, yapılacak araştırmaların reklam çözümlemesine ek olarak, reklam yaratıcıları ve marka yöneticileri ile görüşmelerle desteklenmesi yararlı olacaktır.

Eti Tutku markasının günümüzdeki reklam ajansı olan Güzel Sanatlar'ın Internet sitesinde ("Eti Tutku", n.d.) markanın iletişim stratejisi "Eti Tutku dünyasında tutkunun kökeninde akışkan krema yatıyordu. Absürt ses tonunun da sağladığı alan sayesinde kavramsal tutku, akışkan krema ile yer değiştirerek iletişime taşındı" ifadesiyle açıklanmaktadır. Bu ifadeden de anlaşıldığı üzere reklam yaratıcıları da ürettikleri 
reklam içeriğini absürt olarak nitelemektedir. Sanatsal yaratım sürecinde güdülenlerden daha farklı kaygılarla çevrelenen reklam yaratım sürecinde absürt ya da benzeri yaklaşımların nasıl bir farkındalık ve bilinç düzeyinde ele alındığı ise önemli bir araştırma konusu olarak dikkat çekmektedir. Bu noktada, söz konusu yaklaşımın ne kadar bilinçli olsun ya da olmasın reklam ve sanat ilişkisi açısından değerli olduğu belirtilmelidir. Birer entelektüel, hatta bir görüşe göre birer sanatçı olarak reklamcıların, her ne kadar amaçları bir sanat eseri ortaya koymak olmasa da sanatçılar gibi toplumun diğer üyeleri ile birlikte aynı kültür evreninde yoğrulmuş kişiler oldukları ve doğal olarak absürt ve benzeri sanatsal yaklaşımlardan etkilenmiş oldukları düşünülebilir.

Reklamlarda absürt anlatım dışında farklı teatral anlatım biçimlerine de başvurulduğu gözlemlenmektedir. Pek çok reklam, gerçekçi tiyatroda amaçlanan illüzyonu yaratarak izleyicide olabildiğince güçlü bir gerçeklik deneyimi yaratmaya çalışırken, bazı reklamlarda gerçeklik kasıtlı şekilde kırılarak izleyiciye sunulanın bir reklam olduğu hatırlatılmaktadır. Bu anlatım biçimi, tiyatroyu kitleleri eğitmek ve yönlendirmek için bir araç olarak gören Bertolt Brecht'in Epik Tiyatro anlayışını akla getirmektedir. Brecht, seyircinin sahnedeki illüzyona kapılıp uyuşmasını istemez. Aksine seyircide, sahnelenin bir oyun olduğu bilincini uyanık tutmak ister. Tiyatro yazınında yabancılaştırma olarak adlandıılan bu yaklaşımın günümüz reklamlarında da farklı amaçlarla kullanıldığı dikkat çekmektedir. Esslin'in (1979, p. 104) de belirttiği gibi, Brecht'in politik tiyatrosunun insan davranışlarını etkileme ve toplumu şekillendirme fikrini, onun amaçlarıyla çelişkili ve ironik bir biçimde olsa da reklamlar başarılla gerçekleştirmektedir. Özetle, bu çalışmada absürt dramaturji açısından uygulandığı gibi, gerçekçi, klasik, epik ya da farklı tiyatro yaklaşımları açısından da reklam çözümlemeleri yapılabilecektir.

Bu çalışmada dikkat çekilen yaklaşım; nicel ve nitel içerik analizleri, dilbilimsel, göstergebilimsel ya da metinlerarası çalışmalara benzer bir yaklaşımda olsa da burada söz konusu olan, reklam araştırmalarının sanata ait kavramlarla birlikte, analiz yöntemlerine de başvurması olarak özetlenebilir. Reklamın sanatsal açıdan değerlendirilmesi konusunda, buradaki örneğe benzer şekilde, reklamda öykü anlatım biçimleri, metafor kullanımı, müzik unsuru, grafik tasarım, fotoğraf ve görsel sanatlar gibi farklı noktalara odaklanan araştırmalar da reklamcılık alanına önemli katkılar sağlayacaktır. Bu noktada, söz konusu yaklaşımın ticari bir araç olan reklama gereğinden fazla anlam ve değer yüklüyor olduğu tartışılabilir. Şüphesiz, bir reklamı 
tıpkı bir sanat eseri gibi değerlendirmek ilk bakışta kabul edilebilir bir yaklaşım olarak görülmeyecektir. Bununla birlikte gerek yaratım aşaması, gerek tüketim biçimi sanat eserlerinden çok farklı kaygılarla şekillenen ve farklı biçimlerde gerçekleşen reklamları bu tarz bir değerlendirmeye tabi tutmak, reklamın haksız yere gereğinden fazla yargılanmasına da neden olacaktır. Bu nedenle, burada önerilen yaklaşımda, araştırma nesnesinin yalnızca bir reklam olduğunu unutmamak gerekir. Buradaki örnekte olduğu gibi, tiyatro sanatı ile ilişkili bir yöntem olan dramaturji reklama uygulandığında, yapılan çözümlemenin bir tiyatro metnine kıyasla daha basit bir düzeyde kaldığı görülecektir. Bu durum, çözümlenen içeriğin yapısıyla ilişkilidir. Burada söz konusu olan yaklaşık 30 saniyelik bir kitle iletişim içeriği olan bir reklam filminin çözümlenmesidir. Bunun sonucunda ortaya koyulan bulgular da doğal olarak bu reklamın içeriği ve özellikleri ile sınırlıdır. Oysa bir tiyatro eseri dramaturjik açıdan ele alındığında eserin anlam derinliği ve zenginliği çok daha kapsamlı bir değerlendirmeyi mümkün ve gerekli kılacaktır.

Sonuç olarak, söz konusu bu tartışmayı ve olası eleştirileri de kayda alarak, her ne kadar birer sanat eseri kabul edilmeleri tartışmalı olsa da sanattan bir biçimde izler taşıyan reklamları, sanatın kavram, kuram ve yöntemleri ile çözümlemenin, reklamı daha değerli kılacağı ya da sanatı küçük düşüreceği görüşü de aşırı bir yorum olacaktır. Böylesi bir yaklaşımın gerek ana akım reklam araştırmalarında, gerek eleştirel reklam okumalarında kullanılmasının, yeni, farklı ve ufuk açıcı sonuçlar ortaya koyacak olması göz önünde bulundurulmalıdır.

\section{KAYNAKLAR}

Acarlıoğlu, A. (2003). Saçmanın tiyatrosu. İstanbul, Turkey: Mitos Boyut Yayınları.

Alıcı, B. (2014). Reklam bir sanat mıdır? Celal Bayar Üniversitesi Sosyal Bilimler Dergisi, 12(1), 90-117.

Arias-Bolzmann, L. (1993). An empirical investigation of absurdism's impact on consumer responses to print advertising. (Doctoral dissertation). Oklahoma State University.

Arias-Bolzmann, L., Chakraborty, G., \& Mowen, J. C. (2000). Effects of absurdity in advertising: The moderating role of product category attitude and the mediating role of cognitive responses. Journal of Advertising, 29(1), 35-49.

Aydemir, B. (2003). Absürd tiyatro ve yapısal özellikleri. Atatürk Üniversitesi Güzel Sanatlar Fakültesi Dergisi, 4, 11-29. Baysal, A. (Ed.). (2008). Yeni pazarlama trendleri (3 $3^{\text {rd }}$ ed.). İstanbul, Turkey: MediaCat.

Beckett, S. (1963). Godot'yu beklerken (F. Edgü, Trans.). İstanbul, Turkey: Çan Yayınları.

Berger, J. (2007). Görme biçimleri (Y. Salman, Trans., 13 ${ }^{\text {th }}$ ed.). İstanbul, Turkey: Metis Yayınları. 
Boller, G. W., \& Olson, J. C. (1991). Experiencing ad meanings: Crucial aspects of narrative drama processing. Advances in Consumer Research, 18, 172-175.

Cohen, J. (2001). Defining identification: A theoretical look at the identification of audiences with media characters. Mass Communication and Society, 4(3), 245-264.

Çalışkan, H. (1995). Absürt tiyatro. Ankara, Turkey: İmge Kitabevi.

De Graaf, A., Hoeken, H., Sanders, J., \& Beentjes, J. W. (2012). Identification as a mechanism of narrative persuasion. Communication Research, 39(6), 802-823.

Ergüven, M. S. (2005). Meydan okuyan marka stratejileri ve bir örnek olay incelemesi: Büyük balığı yutan arsız İtalyan - Diesel. Marka Yönetimi Sempozyumu, Gaziantep.

Escalas, J. E. (1998). Advertising narratives: What are they and how do they work. In B. B. Stern (Ed.), Representing consumers: Voices, views, and visions (pp. 267-289). London, UK: Routledge.

Esslin, M. (1979). Aristotle and the advertisers: The television commercial considered as a form of drama. The Kenyon Review, 1(4), 96-108.

Esslin, M. (1996). Dram sanatının alanı: Dram sanatının göstergeleri sahne, perde ve ekrandaki anlamları nasıl yaratır (Ö. Nutku, Trans.). İstanbul, Turkey: Yapı Kredi Yayınları.

Esslin, M. (1999). Absürd tiyatro. (G. Siper, Trans.). Ankara, Turkey: Dost.

Etienne, C., \& Vanbaelen, S. (2006). Paving the way to literary analysis through TV commercials. Foreign Language Annals, 39(1), 87-98.

Eti Tutku. (n.d.). Güzel sanatlar reklam ajansı. Retrieved from http://www.guzelsanatlar.com.tr/etitutku

Eti Tutku. (2011). Eti Tutku 'fal'. Retrieved from https://vimeo.com/22118420

Fisk, R. P., \& Grove, S. J. (1996). Applications of impression management and the drama metaphor in marketing: an introduction. European Journal of Marketing, 30(9), 6-12.

Gelbrich, K., Gäthke, D., \& Westjohn, S. A. (2012). Effectiveness of absurdity in advertising across cultures. Journal of Promotion Management, 18(4), 393-413.

Goffman, E. (2016). Günlük yaşamda benliğin sunumu. (B. Cezar, Trans., $3^{\text {rd }}$ ed.). İstanbul, Turkey: Metis Yayınları. Güllü, F. (1997). Absürd oyunlarda temalar. Mimesis: Tiyatro Çeviri ve Araştırma Dergisi, 6, 361-374.

Hetsroni, A., \& Tukachinsky, R. H. (2005). The use of fine art in advertising: A survey of creatives and content analysis of advertisements. Journal of Current Issues \& Research in Advertising, 27(1), 93-107.

Ionesco, E. (2000a). Toplu oyunları 2: Kel şarkıcı, ders. (H. Anamur, Trans.). İstanbul, Turkey: Mitos Boyut Yayınları.

Ionesco, E. (2000b). Toplu oyunları 4: Gergedanlar, Bavullu adam, Şu kahpe dünya. (H. Anamur, Trans.). İstanbul, Turkey: Mitos Boyut Yayınları.

İpşiroğlu, Z. (1996). Uyumsuz tiyatroda gerçekçilik (2 ${ }^{\text {nd }}$ ed.). İstanbul, Turkey: Mitos Boyut Yayınları.

Karabacak, Z. İ. (2013). Reklam ve sanat ilişkisi. Karadeniz Teknik Üniversitesi Iletişim Araştırmaları Dergisi, 3(5-6), 64-76.

Kılıç Taran, B. (2017). Tüketim toplumunda postmodern sanat akımlarının reklamdaki yansımaları. International Journal of Social Sciences and Education Research, 3(2), 434-447. 
Kim, K., Hayes, J. L., Avant, J. A., \& Reid, L. N. (2014). Trends in advertising research: A Longitudinal Analysis of leading advertising, marketing, and communication journals, 1980 to 2010. Journal of Advertising, 43(3), 296-316.

Meyer, H. M., \& Schulz, S. A. (2017). Dramaturgy of a campaign: Viewing the advertising agency process as a theatrical production. Journal of Promotion Management, 23(4), 504-520.

Moisio, R., \& Arnould, E. J. (2005). Extending the dramaturgical framework in marketing: Drama structure, drama interaction and drama content in shopping experiences. Journal of Consumer Behaviour, 4(4), 246-256.

Okat Özdem, Ö., \& Geçit, E. (2013). Postmodern sanat akımları ve reklamlara yansımaları. Iletişim Kuram ve Araştırma Dergisi, 36, 152-174.

Periasamy, M. S., Gruba, P., \& Subramaniam, G. (2015). A multimodal literary analysis of a television commercial. $3 L$ - Language Linguistics Literature - The Southeast Asian Journal of English Language Studies, 21(3), $151-164$.

Quesenberry, K. A., \& Coolsen, M. K. (2014). What makes a super bowl ad super? Five-act dramatic form affects consumer super bowl advertising ratings. Journal of Marketing Theory and Practice, 22(4), 437-454.

Rutherford, P. (2000). Yeni ikonalar: Televizyonda reklam sanatı. (M. K. Gerçeker, Trans., $2^{\text {nd }}$ ed.). İstanbul, Turkey: Yapı Kredi Yayınları.

Schulz, H. M. (2012). Exploring dramaturgy in consumer research. Journal of Research for Consumers, 21, 1-19.

Stern, B. B. (1990). Marketing as drama: Theatre of the absurd. Research in Consumer Behaviour, 4. 189-209.

Stern, B. B. (1991). Literary analysis of an advertisement: The commercial as "soap opera". Advances in Consumer Research, 18(1), 164-171.

Stern, B. B. (1992). Crafty advertisers: Literary versus literal deceptiveness. Journal of Public Policy and Marketing, $11(1), 72-81$

Stern, B. B. (1994). Classical and vignette television advertising dramas: Structural models, formal analysis, and consumer effects. Journal of Consumer Research, 20(4), 601-615.

Stern, B. B. (1996). Textual analysis in advertising research: Construction and deconstruction of meanings. Journal of Advertising, 25(3), 61-73.

Stern, B. B., \& Schroeder, J. E. (1994). Interpretative methodology from art and literary criticism: A humanistic approach to advertising imagery. European Journal of Marketing, 28(8-9), 114-132.

Şener, S. (1998). Dünden bugüne tiyatro düşüncesi (3 $3^{\text {rd }}$ ed.). Ankara, Turkey: Dost Kitabevi.

Uztuğ, F. (2008). Markan kadar konuş (4 ${ }^{\text {th }}$ ed.). İstanbul, Turkey: Mediacat.

Yıldız, S., \& Uztuğ, F. (2017). Reklamda absürtlüğün reklama yönelik tutum ve hatırlama üzerine etkileri. Karadeniz Teknik Üniversitesi İletişim Fakültesi Elektronik Dergisi, 4(13), 96-117.

Yılmaz, R. (2017). Televizyon reklamlarında metaleptik kullanımların tipolojisi. Gümüşhane Üniversitesi Illetişim Fakültesi Elektronik Dergisi, 5(2), 691-704. 


\section{GÖRSELLER}

\section{Görsel 1: Eti Tutku “Fal” Reklamı}
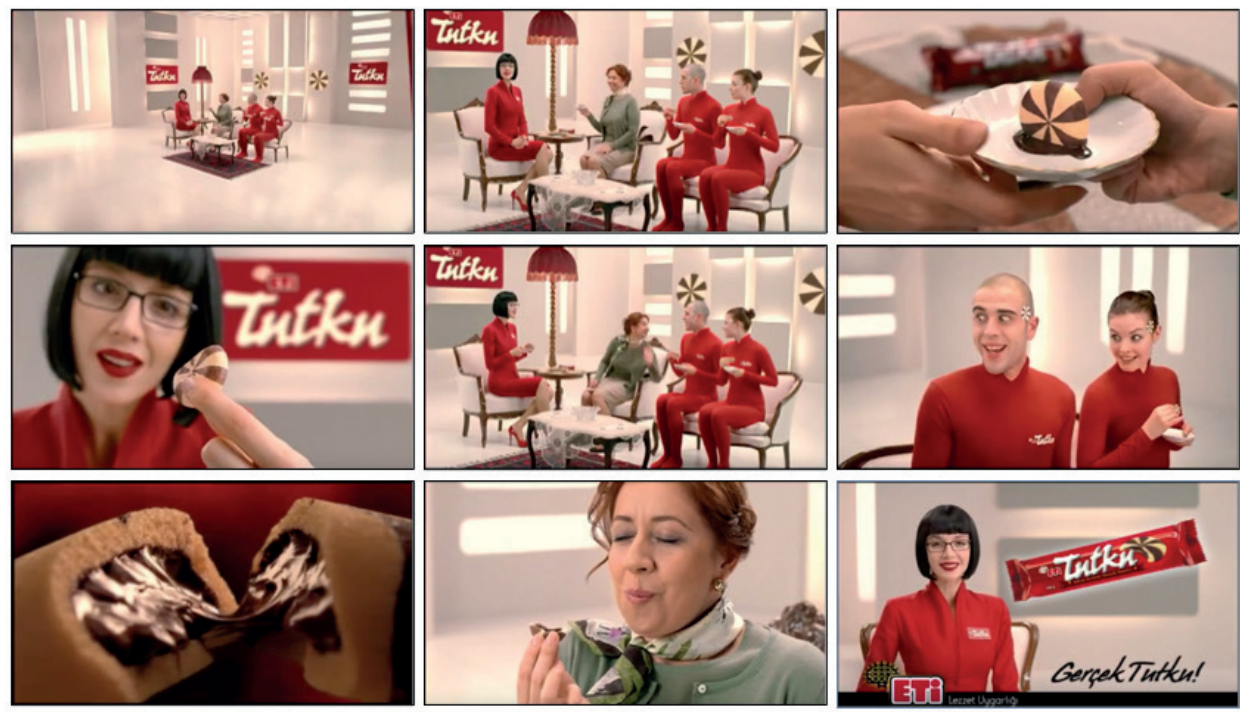
